US Army Corps

of Engineers

Waterways Experiment

Station

\title{
An Analysis of Freshwater Mussels (Unionidae) Along Luxapalila Creek, Mississippi
}

by Andrew C. Miller 
The contents of this report are not to be used for advertising, publication, or promotional purposes. Citation of trade names does not constitute an official endorsement or approval of the use of such commercial products.

The findings of this report are not to be construed as an official Department of the Army position, unless so designated by other authorized documents. 


\section{An Analysis of Freshwater Mussels (Unionidae) Along Luxapalila Creek, Mississippi}

by Andrew C. Miller

U.S. Army Corps of Engineers

Waterways Experiment Station

3909 Halls Ferry Road

Vicksburg, MS 39180-6199

Final report

Approved for public release; distribution is unlimited 


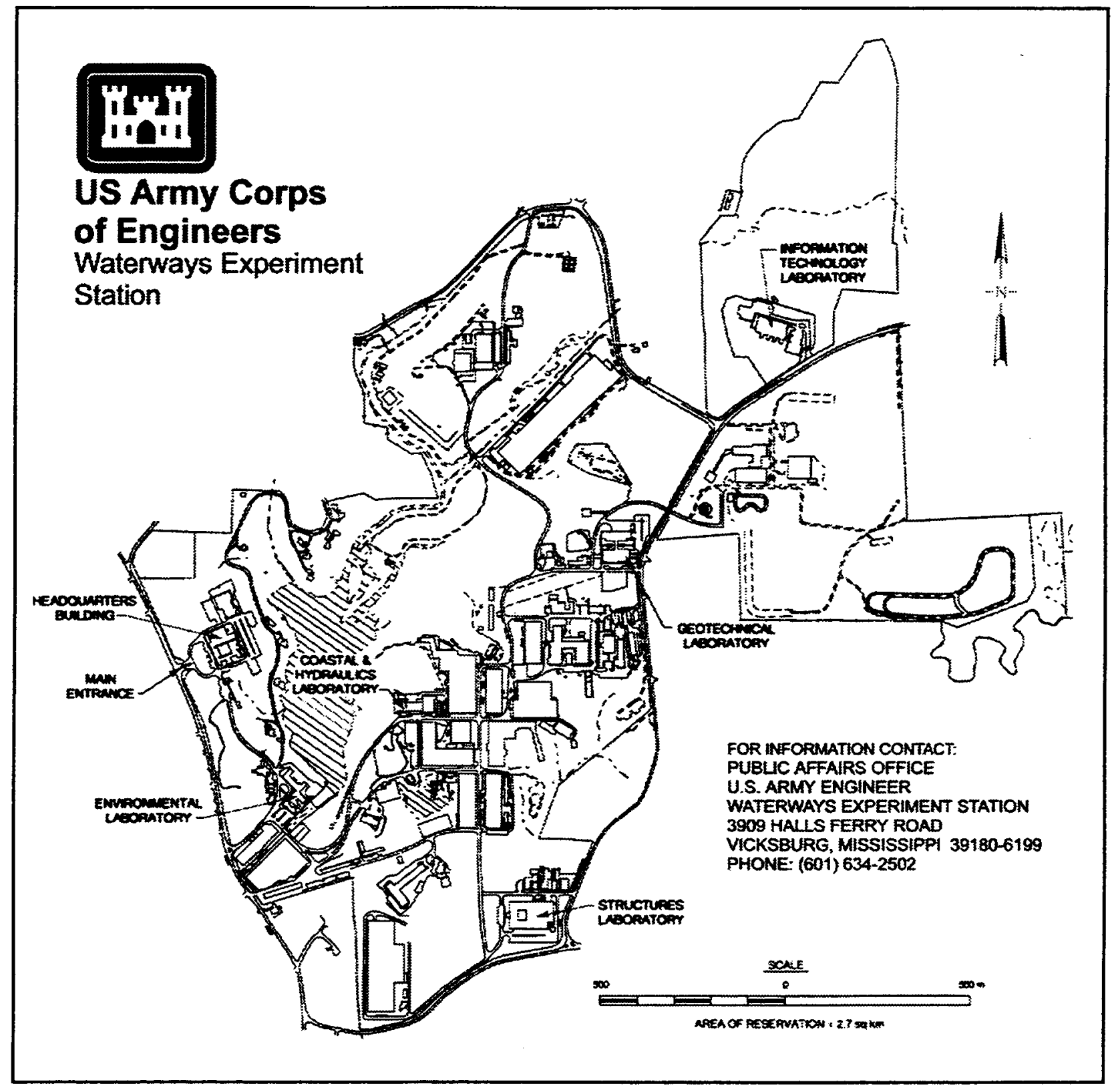

\section{Waterways Experiment Station Cataloging-in-Publication Data}

Miller, Andrew C.

An analysis of freshwater mussels (Unionidae) along Luxapalila Creek, Mississippi / by Andrew C.

Miller ; prepared for U.S. Army Engineer District, Mobile.

23 p. : ill. ; $28 \mathrm{~cm}$. - (Technical report ; EL-98-14)

Includes bibliographic references.

1. Unionidae - Mississippi - Luxapalila Creek. 2. Freshwater mussels - Mississippi - Luxapalila. I. United States. Army. Corps of Engineers. Mobile District. II. U.S. Army Engineer Waterways Experiment Station. III. Environmental Laboratory (U.S. Army Engineer Waterways Experiment Station) IV. Title. V. Series: Technical report (U.S. Army Engineer Waterways Experiment Station) ; EL-98-14.

TA7 W34 no.EL-98-14 


\section{Contents}

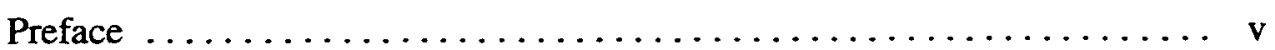

Conversion Factors, Non-SI to SI Units of Measurement ........... vii

1 -Introduction $\ldots \ldots \ldots \ldots \ldots \ldots \ldots \ldots \ldots \ldots \ldots \ldots \ldots \ldots \ldots \ldots \ldots$

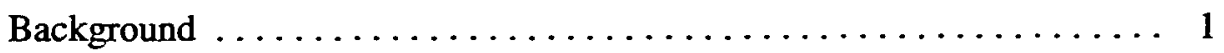

Mussels of Luxapalila Creek ......................... 2

Purpose and Scope ................................. 2

2-Study Area and Methods $\ldots \ldots \ldots \ldots \ldots \ldots \ldots \ldots \ldots \ldots \ldots \ldots \ldots \ldots \ldots$

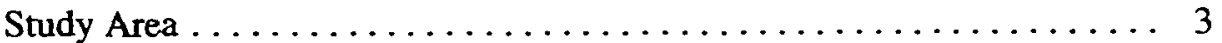

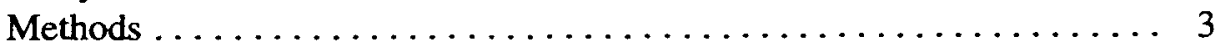

3-Results and Discussion ........................ 6

Characterization of Mussel Resource .................... 6

Effects of Channel Modifications on Water Velocity ............. 11

Summary and Recommendations ..................... 13

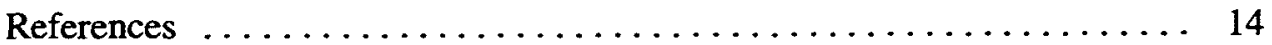

SF 298

\section{List of Tables}

Table 1. Coordinates for Sites Surveyed on Luxapalila Creek, Mississippi, 19 August 1997 .................... 5

Table 2. Freshwater Mussels Collected at Sites Along Luxapalila Creek, Mississippi, 19 August 1997 . . . . . . . . . . . . . . 7

Table 3. Live Mussels Collected Along Luxapalila Creek by Hartfield and Bowker (1992) . . . . . . . . . . . . . 8 
Table 4. Freshwater Mussels of Luxapalila Creek .......... 10

Table 5. Preproject and Postproject Water Velocity Values, and Differences Between the Two, in Luxapalila Creek, Following Channel Maintenance Downstream of Waterworks Bridge Road . . . . . . . . . . . . . . . . . 11 


\section{Preface}

In 1997, a survey for freshwater mussels was conducted along Luxapalila Creek, Mississippi, between Steens, MS, River Mile (RM) 16.3, and Waterworks Road bridge, RM 6.2. The purpose was to obtain information that could be used to assess the effectiveness of reasonable and prudent measures and their terms and conditions to reduce impacts to mussels caused by downstream channelization during 1994 and 1995, which increased water velocity. In addition, results would be used to determine the likelihood of future losses, or incidental take, of Federally listed species in the project area. Studies were conducted by the U.S. Army Engineer Waterways Experiment Station (WES).

This report was prepared by Dr. Andrew C. Miller, Aquatic Ecology Branch (AEB), Ecological Research Division (ERD), Environmental Laboratory (EL), WES.

Divers for the project were Messrs. Larry Neill, Johnny Buchanan, Rob James, and Dennis Baxter from the Tennessee Valley Authority. Assistance in the field was provided by Mr. Will Green and Dr. David C. Beckett, University of Southem Mississippi, and Messrs. Phil Fishella and John Defillipo, U.S. Army Engineer District, Mobile (Columbia Area Office). Mr. Brian Peck, U.S. Army Engineer District, Mobile (Planning and Environmental Division), provided maps and other background information on the project area.

During the conduct of this study and publication of this report, Dr. John Harrison was Director, EL; Dr. Conrad J. Kirby was Chief, ERD; Dr. Alfred F. Cofrancesco was Acting Chief, AEB; and Dr. Edwin A. Theriot was Chief, AEB.

At the time of publication of this report, Director of WES was Dr. Robert W. Whalin. Commander was COL Robin R. Cababa, EN. 
This report should be cited as follows:

Miller, A. C. (1998). "An analysis of freshwater mussels (Unionidae) along Luxapalila Creek, Mississippi," Technical Report EL-98-14, U.S. Army Engineer Waterways Experiment Station, Vicksburg, MS.

The contents of this report are not to be used for advertising, publication, or promotional purposes. Citation of trade names does not constitute an official endorsement or approval of the use of such commercial products. 


\section{Conversion Factors, Non-SI to SI Units of Measurement}

Non-SI units of measurement used in this report can be converted to SI units as follows:

\begin{tabular}{||l|l|l|}
\hline Multiply & By & To Obtain \\
\hline \hline cubic feet & 0.02831685 & cubic meters \\
\hline feet & 0.3048 & meters \\
\hline miles (U.S. nautical) & 1.852 & kilometers \\
\hline
\end{tabular}




\section{Introduction}

\section{Background}

Channelization and widening of the Columbus reach of Luxapalila Creek, located in east-central Mississippi, began in September 1994. Work started at River Mile (RM) 2.1, moved upriver until December of that year, and then resumed in June 1995. Work continued through December 1995 when high flow prevented completion of the final $0.37 \mathrm{~km}(0.2 \text { miles })^{1}$ of the upper Columbus reach. (The final $0.37 \mathrm{~km}$ (0.2 miles) was completed in 1996). During this period, the reach immediately upriver of Waterworks Road bridge (RM 6.2) was unprotected from higher water velocities and decreased water surface elevations that resulted from the increased slope and drainage efficiency of the downstream reach. On 15 March 1996, the U.S. Fish and Wildlife Service (USFWS) contacted the U.S. Army Engineer District, Mobile, concerning Luxapalila Creek. They had received information from the Mississippi Department of Wildlife, Fisheries and Parks (MDWFP) concerning degradation upriver of Waterworks Road bridge. A visit revealed streambank erosion and undercutting, bank failure with fallen trees, increased water velocities, decreased water surface elevations, recent gravel bar reworking and deposition, scoured water willow beds, and significant shifts in channel thalweg (USFWS 1996). Field investigations by the MDWFP indicated that the effects of channel instability were continuing and were evident at least up to RM 8.2 (Mr. Charles Watts as cited by USFWS 1996). These observations suggested that significant channel degradation and erosion had recently occurred in response, at least in part, to the downstream channelization between RM 2.1 and 6.0.

The project area is within the range of the following federally listed endemic mussels: Pleurobema perovatum (ovate clubshell mussel) and Pleurobema decisum (southern clubshell mussel), listed as endangered; and Medionidus acutissimus (Alabama moccasinshell mussel) and Lampsilis perovalis (orangenacre mucket mussel) listed as threatened. These species originally occurred widely in the Tombigbee River drainage, including the Tombigbee River and some of its larger tributaries. These riverine species inhabit high quality, stable gravel or gravel and sand with flowing water.

\footnotetext{
I A table of factors for converting non-SI units of measurement to SI units is presented on page vii.
} 
At the request of the Mobile District, the USFWS prepared a Biological Opinion that provided reasonable and prudent measures (RPMs) and their terms and conditions (T\&C) to avoid or minimize incidental "take" of federally listed mussel species. Among the RPMs and their T\&C to be implemented by the Mobile District was the monitoring of mussel populations upstream from Waterworks Road bridge. Results of this monitoring, in conjunction with hydrologic monitoring at selected cross-section stations to be conducted by the Mobile District, would be used to assess the effectiveness of RPMs and their $\mathrm{T} \& \mathrm{C}$ to reduce impacts to mussels. Results will also be used to determine the likelihood of future losses or incidental take of federally listed species.

\section{Mussels of Luxapalila Creek}

The first published list of mussels in Luxapalila Creek was by C.A. Schultz (1981). In addition to reporting on fishes in the Tombigbee River before construction of the Tennessee-Tombigbee Waterway, he listed freshwater mussels from the entire basin including 13 species from Luxapalila Creek. Personnel from the Mississippi Museum of Natural Science collected mussels in Luxapalila Creek in the 1980s and early 1990s (Hartfield and Bowker 1992). The present survey is the third major mussel study of Luxapalila Creek.

\section{Purpose and Scope}

The purpose was to collect information on mussels in Luxapalila Creek upstream of Waterworks Road bridge to evaluate effects of recent channel modifications and project-induced water velocity changes. 


\section{Study Area and Methods}

\section{Study Area}

Luxapalila Creek begins as three small creeks in western Alabama near the border of Lamar and Pickens counties (Figure 1). The creeks flow west into Mississippi to form Luxapalila Creek in eastern Lowndes County, then joins Yellow Creek west of Steens, MS. Luxapalila Creek then flows southwest through Columbus where it enters the Tombigbee River. The project area begins near Steens and continues to Waterworks Road bridge, a distance of approximately $13 \mathrm{~km}$ (7 miles) (Figure 1$)$.

Between Steens and the confluence of Yellow Creek, Luxapalila Creek was narrow with steep banks ( 1 to $2 \mathrm{~m}$ ) and sharp bends. There were no exposed shoals, and current velocity ranged between 25 and $50 \mathrm{~cm} / \mathrm{sec}$. Between the confluence of Yellow Creek and just downriver of the last site sampled (Figure 1), the creek consisted of a sequence of long, narrow pools, runs, and riffles. During the time of the survey, water velocity ranged between 25 and $50 \mathrm{~cm} / \mathrm{sec}$, and the habitat consisted of shallow runs, riffles, and exposed bars. Pools with fine-grained silt substratum were behind many of the exposed shoals. Between the last site sampled and Waterworks Road bridge, there were fewer exposed gravel shoals, the water was deeper, and velocity was approximately $75 \mathrm{~cm} / \mathrm{sec}$. Mussels were collected at specific sites between RM 14.6 and 10.1 (Table 1).

\section{Methods}

A reconnaissance of the study area was conducted with personnel from the Mobile District and USFWS on 14 November 1996. U.S. Geological Survey topographic maps were used to identify potential mussel collecting sites. In midJuly, personnel from the U.S. Army Engineer Waterways Experiment Station traveled the project area in a small boat and revisited potential sampling sites. Water levels were checked, and a few live mussels and shells were collected. The purpose was to obtain more background information on water levels, substratum conditions, and current velocity. 


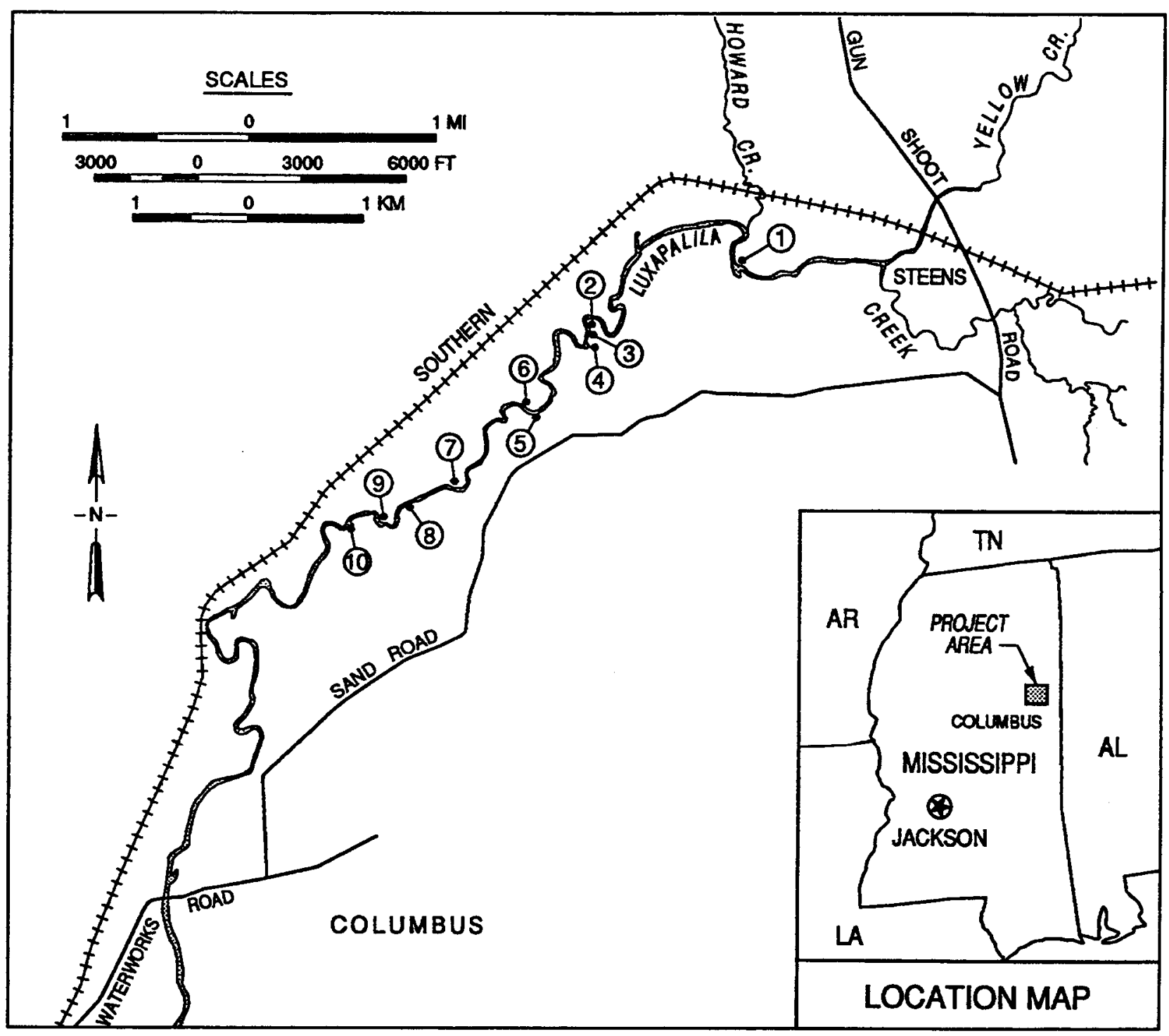

Figure 1. Map of study area

On 19 August, a crew consisting of divers and nondivers searched for mussels in the study area (Figure 1, Table 1). Two divers worked in deep water for specific time periods, usually $30 \mathrm{~min}$. They moved on their hands and knees and collected all live bivalves encountered by touch. While the divers worked, from five to seven nondivers searched water less than $1 \mathrm{~m}$ deep using basically the same methods. In addition, at each site two to three quantitative, total substratum samples were obtained, and sediments were wet-sieved through a screen series and carefully examined for live juveniles. Although more tedious, total substratum sampling is more likely to obtain live juveniles than qualitative collecting by hand. Total area of bottom sampled quantitatively is listed in Table 1. 


\begin{tabular}{|c|c|c|c|c|}
\hline \multicolumn{5}{|c|}{$\begin{array}{l}\text { Table } 1 \\
\text { Coordinates for Sites Suveyed on Luxapalila Creek, Mississippi, } 19 \text { August } 1997 \text { (nd = } \\
\text { no data) (Total number of meters or river bottom searched for mussels using a quadrat } \\
\text { sampler is noted for each site) }\end{array}$} \\
\hline Sample Site & River Mile & Latitude & Longitude & Notes \\
\hline 1 & 14.6 & 3333.919 & 8820.409 & $\begin{array}{l}\text { Slough on left-descending bank (LDB), considerable amount of } \\
\text { exposed sand and gravel at the site, which was located along a } \\
\text { sharp right tum in the river. Shells were found along the shoreline } \\
\text { although only one live mussel was collected by a diver. Total } \\
\text { quantitative samples }=3 \mathrm{sq} \mathrm{m} \text {. }\end{array}$ \\
\hline 2 & 12.8 & 3332.652 & 8821.277 & $\begin{array}{l}\text { At an exposed sand and gravel shoal located along the LDB. Most } \\
\text { common thick-shelled live mussels were collected in shallow water } \\
\text { immediately upriver of a sharp right tum and embayment with fine } \\
\text { sand and silt substratum. Many mussels were also collected by } \\
\text { divers in the embayment. Total quantitative samples }=5 \mathrm{sq} \mathrm{m} \text {. }\end{array}$ \\
\hline 3 & 12.7 & 3333.515 & 8821.255 & $\begin{array}{l}\text { This site was in an embayment on the LDB next to a sharp right tum } \\
\text { in the river. Sediments consisted of flocculent, fine-grained sitt and } \\
\text { sand. No mussels were taken at this tocation. Total quantitative } \\
\text { samples }=3 \mathrm{sq} \mathrm{m} \text {. }\end{array}$ \\
\hline 4 & 12.6 & 3333.491 & 8821.265 & $\begin{array}{l}\text { This site was along the LDB approximately } 100 \text { m upriver of Site } 3 \text {. } \\
\text { The site was along a straight reach of river immediately downriver of } \\
\text { a sharp left turn in the river. This was not a very productive site for } \\
\text { mussels. Total quantitative samples }=3 \text { sq } \mathrm{m} \text {. }\end{array}$ \\
\hline 5 & 11.9 & 3333.433 & 8821.365 & $\begin{array}{l}\text { An exposed gravel shoal along the right-descending bank (RDB) } \\
\text { immediately upriver of a right turn in the river. This was not a very } \\
\text { productive site for mussels. Total quantitative samples }=3 \mathrm{sq} \mathrm{m} \text {. }\end{array}$ \\
\hline 6 & 111.7 & 3333.289 & 8821.515 & $\begin{array}{l}\text { Exposed sand and gravel along the shore and shallow, moderately } \\
\text { high velocity water }(40 \mathrm{~cm} / \mathrm{sec}) \text { along the RDB. Divers found a few } \\
\text { mussels in an embayment downriver of the shoal. A site similar to } \\
\text { Number } 3 \text {. Not a very productive site. Total quantitative samples = } \\
3 \mathrm{sq} \mathrm{m} \text {. }\end{array}$ \\
\hline 7 & 10.9 & 3333.202 & 8821.537 & $\begin{array}{l}\text { A shoal along the RDB immediately upriver of a shap right tum. No } \\
\text { live mussels were collected. Total quantitative samples }=3 \mathrm{sq} \mathrm{m} \text {. }\end{array}$ \\
\hline 8 & 10.5 & 3333.194 & 8821.774 & $\begin{array}{l}\text { Exposed gravel shoal along the LDB. Not a very productive site. } \\
\text { Total quantitative samples }=3 \mathrm{sq} \mathrm{m} \text {. }\end{array}$ \\
\hline 9 & 10.3 & 3333.800 & 8822.152 & $\begin{array}{l}\text { Collections were made along either side and immediately upriver of a } \\
\text { vegetated gravel shoal located nearly in the center of the river. Not a } \\
\text { very productive site. Total quantitative samples }=3 \mathrm{sq} \mathrm{m} \text {. }\end{array}$ \\
\hline 10 & 10.1 & nd & nd & $\begin{array}{l}\text { The most productive site worked. All mussels were collected in an } \\
\text { embayment immediately downiver of a gravel shoal along the LDB. } \\
\text { Total quantitative samples }=5 \mathrm{sg} \mathrm{m} \text {. }\end{array}$ \\
\hline
\end{tabular}

At the end of the collecting period, mussels and shells from each site were counted and identified. Representative shells of each species were retained for voucher; most live organisms were returned to the river unharmed. Specimens were compared with shells in the reference collection at the Mississippi Museum of Natural Science. More information on methods for sampling can be found in Isom and Gooch (1986); Kovalak, Dennis, and Bates (1986); Miller and Payne (1988); and Miller et al. (1993). Mussel taxonomy is consistent with Williams et al. (1993). 


\section{Results and Discussion}

\section{Characterization of Mussel Resource}

A total of 15 species of bivalves, including Corbicula fluminea (Asian clam), was collected during the survey. Total search time expended was 1,230 min $(20.5 \mathrm{hr}$ ) and ranged from $205 \mathrm{~min}$ at Site 2 to $30 \mathrm{~min}$ at Site 3 (Table 2). On average, the greatest number of mussels collected per minute was at Sites 2 $(0.278 / \mathrm{min})$ and $10(0.195 / \mathrm{min})$. Nine species were collected at each of these two sites, whereas only three species were collected at the next two richest sites (Numbers 6 and 9). At five sites, between two and five live bivalves were found, and at two sites, no live bivalves were collected (Table 3). Three species were represented only by shells: Toxolasma parvus (lilliput), Potamilus purpuratus (bleufer), and Pleurobema decisum (southern clubshell). It is likely that live specimens of these species were present but not collected during the survey.

A total of 124 bivalves were collected. The majority, 103 or $83 \%$, were found in water less than $1.0 \mathrm{~m}$ deep by nondivers. Typically, water velocity in the deeper areas did not provide very good habitat for mussels. Therefore, having divers assist probably did not affect the outcome of this study very much.

Mussel collecting rates ranged from 0.01 to 0.278 individuals/minute; mean collecting rate was 0.101 individuals/minute (Table 2). Using similar techniques, divers have collected up to eight mussels/minute in moderate- to high-density beds in the upper Mississippi River, Wisconsin (Miller and Payne 1996), and in the Sunflower River, central Mississippi (Miller and Payne 1995). Density in the majority of these sites along Luxapalila Creek, when compared with mediumsized to large rivers in the central and southeastern United States, is moderate to low. Based upon the results of quantitative sampling, no juvenile mussels were found. However, it is always possible that numbers of very small mussels were so low that they were simply not collected during this survey.

Based upon living specimens, the most abundant species were Quadrula asperata (Atlanta orb) and Lampsilis straminea claiborensis (southern fatmucket), which comprised 44.3 and 19.3 percent of the fauna. Both species are relatively common in sand gravel substratum in southern streams. The third most abundant species, Lampsilis straminea claiborensis (southern pocketbook), comprised slightly more than 10 percent of the collection. This species is 


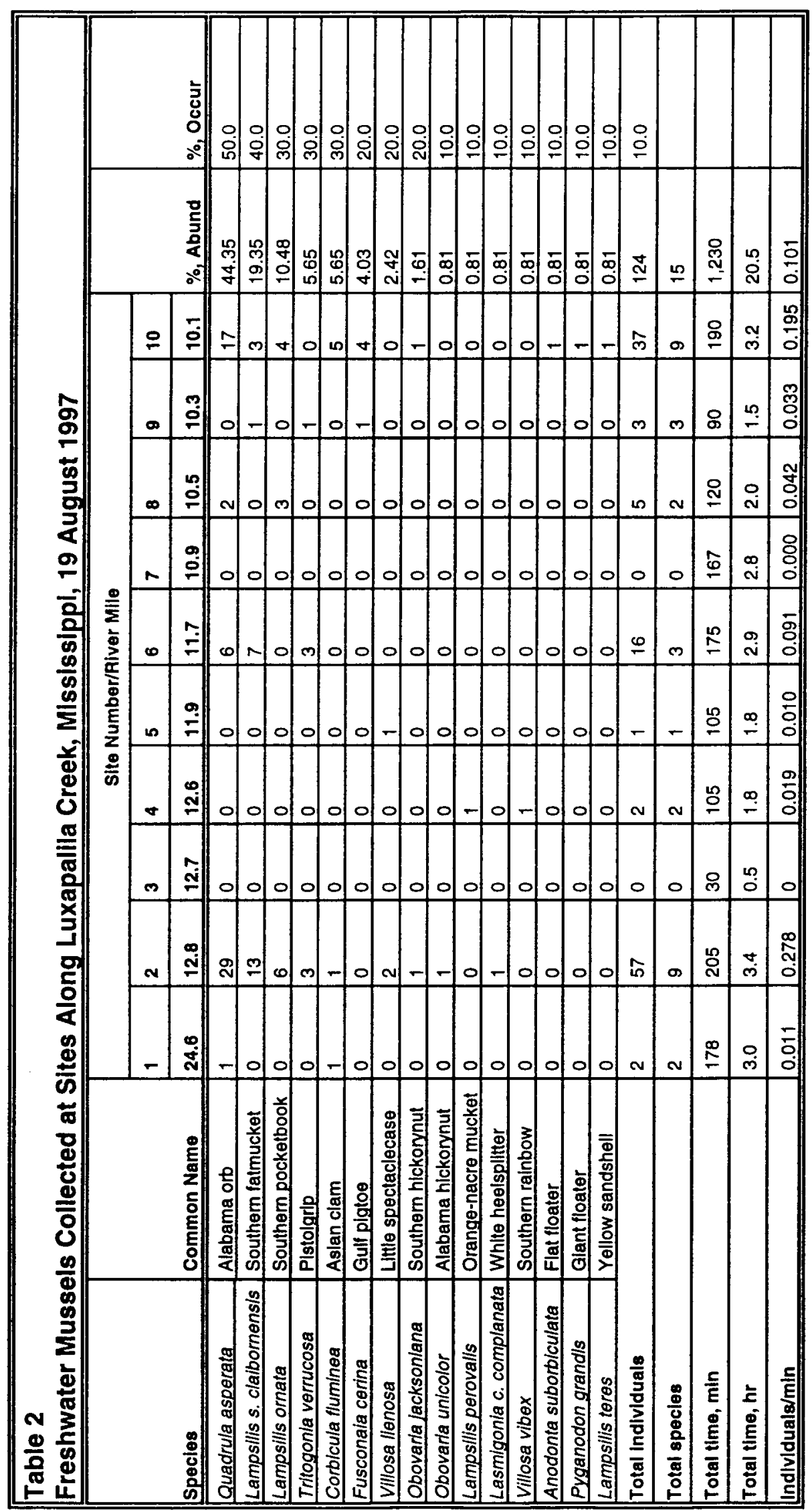




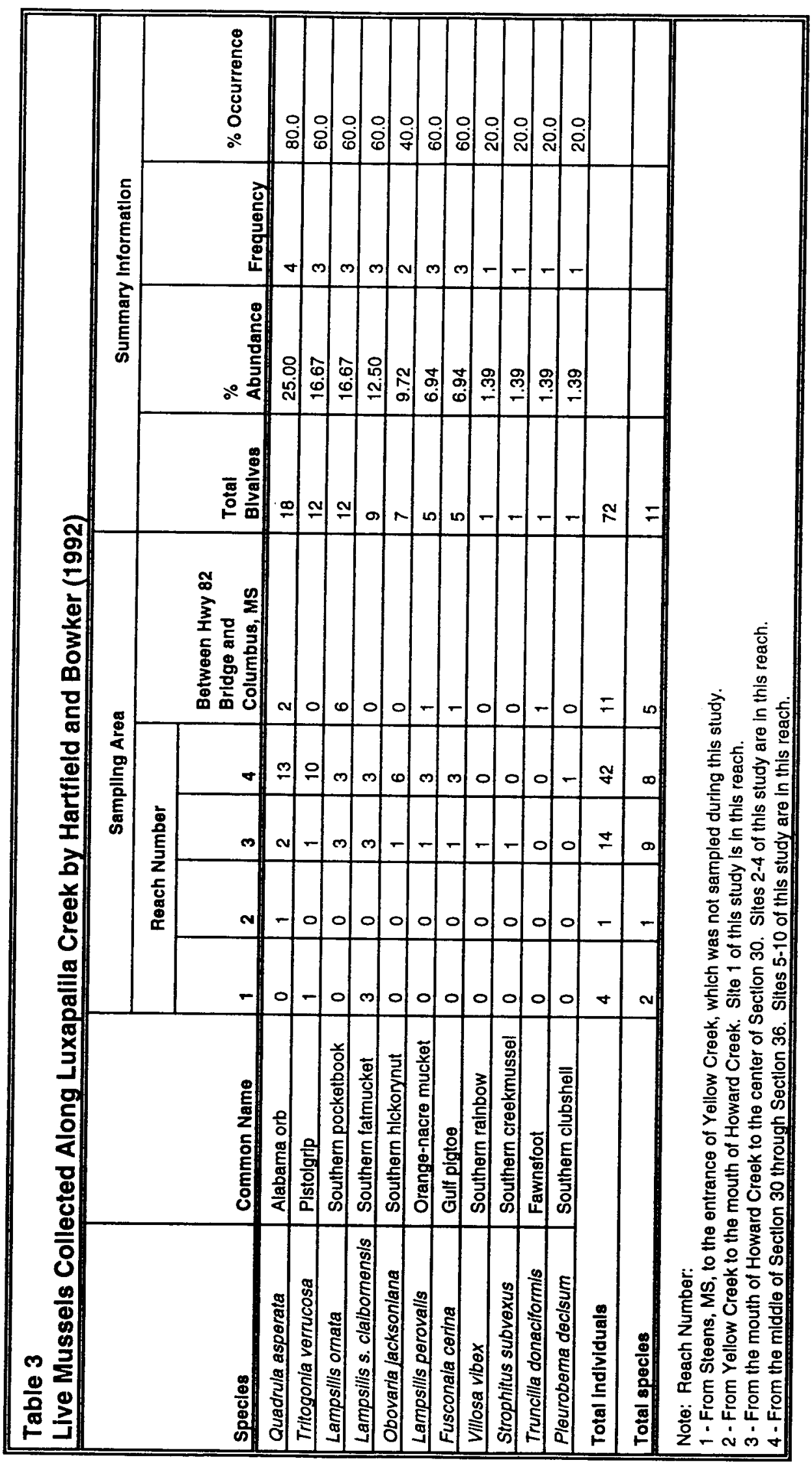


common in fine-grained sand or silt substratum in lentic or lotic habitats in Mississippi. The remaining 12 species (including Corbicula fluminea) each comprised less than 6 percent of the fauna.

Hartfield and Bowker (1992) searched for bivalves along Luxapalila Creek on 11-12 May 1992. Collections were made by hand; no diving was done.

Sampling methods used during both surveys are approximately similar, since as noted above, the majority of the mussels collected during the 1997 survey were obtained by nondivers. Hartfield and Bowker (1992) reported on live mussels from the following reaches (moving downriver):

Reach 1 - From Steens to the entrance of Yellow Creek.

Reach 2 - From the entrance of Yellow Creek to the mouth of Howard Creek. Reach 3 - From the mouth of Howard Creek to the center of Section 30 (near Site 1 of this study, see Figure 1).

Reach 4 - From Section 30 through Section 36 (downriver of last site of this study, see Figure 1).

In addition to Corbicula fluminea, they collected 11 species of mussels and 72 individuals (Table 3). They found live specimens of Pleurobema decisum and Strophitus subvexus (southern creek mussel), which this study did not find or reported only as shells. In the present survey, the following six species were collected alive that were not taken by Hartfield and Bowker: Lampsilis teres (yellow sandshell), Toxolasma parvus, Anodonta suborbiculata (flat floater), Lasmigonia complanata (white heelsplitter), and Obovaria unicolor (Alabama hickorynut), and Pyganodon grandis (giant floater). With the exception of Lampsilis teres and Toxolasma parva, the latter four species had not been previously reported from Luxapalila Creek. It is possible that these latter were either missed during previous surveys, or that they have been recently introduced.

Based upon results of his studies and historical information, Hartfield and Bowker (1992) listed 21 species of mussels from Luxapalila Creek (Table 4). Their list included four previously unreported species: Elliptio arca (Alabama spike), Fusconaia cerina (Gulf pigtoe), Potamilus purpuratus, and Megalonaias nervosa (Washboard). Only Fusconaia cerina was taken alive; the remainder were collected as shells. During this study, 14 living species of native mussels were collected including 4 that had never been reported from the project area: Anodonta suborbiculata (flat floater), Lasmigonia complanata (white heelsplitter), Obovaria unicolor (Alabama hickorynut), and Pyganodon grandis (giant floater). This brings the total list for Luxapalila Creek to 25 species of freshwater mussels. 


\begin{tabular}{|c|c|c|c|c|c|}
\hline \multicolumn{6}{|c|}{$\begin{array}{l}\text { Table } 4 \\
\text { Freshwater Mussels of Luxapalila Creek (Information in Column } 3 \text { was published in the } \\
\text { report by Hartfield and Bowker (1992), includes information obtained by Schultz (1981), } \\
\text { and includes historical information as well as results of recent collections. Although } \\
\text { not listed, Corbicula fluminea has been collected regularly from Luxapalila Creek at } \\
\text { least since } 1980 \text { (Schultz 1981)) }\end{array}$} \\
\hline Species & Common Name & $\begin{array}{l}\text { Schultz } \\
\text { Survey, } \\
1980 \\
\end{array}$ & \begin{tabular}{|l} 
Hartfield and \\
Bowker Survey, \\
1992 \\
\end{tabular} & $\begin{array}{l}\text { Mussels From } \\
\text { the Project } \\
\text { Area } \\
\end{array}$ & $\begin{array}{l}\text { WES' } \\
\text { Survey, } \\
1997 \\
\end{array}$ \\
\hline Anodonta suborbiculata & Flat floater & & & & $x$ \\
\hline Elliptio arctata & Delicate spike & $x$ & & $x$ & \\
\hline Elliptio arca & Alabama spike & & & $x$ & \\
\hline Elliptio crassidens & Elephant-ear & $x$ & & $x$ & \\
\hline Fusconaia cerina & Gulf pigtoe & & $x$ & $x$ & $x$ \\
\hline Lampsilis s. claibomensis & Southem fatmucket & $x$ & $x$ & $x$ & $x$ \\
\hline Lampsilis omata & Southem pocketbook & $x$ & $x$ & $x$ & $x$ \\
\hline Lampsilis perovalis & Orange-nacre mucket & & $x$ & $x$ & $x$ \\
\hline Lampsilis teres & Yellow sandshell & $x$ & & $x$ & $x$ \\
\hline Lasmigonia c. complanata & White heelsplitter & & & & $x$ \\
\hline Medionidus acutissimus & Alabama moccasinshell & & & $x$ & \\
\hline Megalonaias nervosa & Washboard & & & $x$ & \\
\hline Obovaria jacksoniana & Southem hickorynut & $x$ & $x$ & $x$ & $x$ \\
\hline Obovaria unicolor & Alabama hickorynut & & & & $x$ \\
\hline Pleurobema decisum & Southem clubshell & $x$ & $x$ & $x$ & \\
\hline Pleurobema perovatum & Ovate clubshell & $x$ & & $x$ & \\
\hline Potamilus purpuratus & Bleufer & & & $x$ & \\
\hline Pyganodon grandis & Giant floater & & & & $x$ \\
\hline Quadrula asperata & Alabama ort & $x$ & $x$ & $x$ & $x$ \\
\hline Strophitus subvexus & Southem creekmussel & $x$ & $x$ & $x$ & \\
\hline Toxolasma parvus & Lilliput & & & $x$ & \\
\hline Tritogonia vernucosa & Pistolgrip & $x$ & $x$ & $x$ & $x$ \\
\hline Truncilla donaciformis & Fawnsfoot & & $x$ & $x$ & \\
\hline Villosa lienosa & Little spectaclecase & $x$ & & $x$ & $x$ \\
\hline Villosa vibex & Southem rainbow & $x$ & $x$ & $x$ & $x$ \\
\hline \multicolumn{2}{|l|}{ Total species } & 13 & 11 & 21 & 14 \\
\hline
\end{tabular}




\section{Effects of Channel Modifications on Water Velocity}

The HEC-2 Model was used to evaluate the effects of completed channel modifications downstream of Waterworks Road bridge on water velocity (see Table 5). Differences between preproject and postproject water velocities were least $(<0.03 \mathrm{~m} / \mathrm{sec}(<0.1 \mathrm{ft} / \mathrm{sec}))$ at low discharge and greatest $(>0.106 \mathrm{~m} / \mathrm{sec}$ $(>0.35 \mathrm{ft} / \mathrm{sec})$ ) at high discharge. Mean water velocity values were highest at the downstream portion of the study area. At RM 6.11 and 7.18, mean velocity differences between preproject and postproject conditions were greater than $0.15 \mathrm{~m} / \mathrm{sec}(0.5 \mathrm{ft} / \mathrm{sec})$. At the most upstream river reaches, differences between preproject and postproject water velocity approached 0 .

\begin{tabular}{|c|c|c|c|c|c|c|c|}
\hline \multicolumn{8}{|c|}{$\begin{array}{l}\text { Table } 5 \\
\text { Preproject and Postproject Water Velocity Values, and Differences Between the Two, in } \\
\text { Luxapalila Creek, Following Channel Maintenance Downstream of Waterworks Bridge } \\
\text { Road (RM 6.09) (Data from the HEC-2 model was used to analyze effects of the grade } \\
\text { control structure on Luxapalila Creek (Mr. Cecil Jernigan, Personal Communication, } \\
\text { Mobile District)) }\end{array}$} \\
\hline \multicolumn{4}{|c|}{ Velocity Changes at Eight Discharge Values } & \multicolumn{4}{|c|}{ Velocity Changes at Seven Stations } \\
\hline $\begin{array}{l}\text { Stream } \\
\text { Discharge cfs }\end{array}$ & Preproject & Postproject & $\begin{array}{l}\text { Postproject - } \\
\text { Preproject } \\
\text { ft/sec }\end{array}$ & \begin{tabular}{|l} 
River \\
Station \\
(River Mile)
\end{tabular} & Preproject & Postproject & $\begin{array}{l}\text { Postproject- } \\
\text { Preproject ff/sec }\end{array}$ \\
\hline 220 & 1.34 & 1.37 & 0.04 & 6.11 & 1.39 & 2.10 & 0.72 \\
\hline 485 & 1.75 & 1.81 & 0.06 & 7.18 & 2.61 & 3.24 & 0.63 \\
\hline 1,190 & 1.84 & 1.96 & 0.12 & 8.12 & 2.46 & 2.63 & 0.17 \\
\hline 2,000 & 2.12 & 2.30 & 0.18 & 9.03 & 1.94 & 2.01 & 0.07 \\
\hline 3,000 & 2.41 & 2.65 & 0.24 & 9.45 & 1.96 & 2.03 & 0.07 \\
\hline 5,000 & 2.61 & 2.94 & 0.33 & 11.62 & 2.74 & 2.73 & -0.01 \\
\hline 7,500 & 2.90 & 3.25 & 0.35 & 13.16 & 1.65 & 1.65 & 0.0 \\
\hline 10,000 & 3.14 & 3.54 & 0.40 & nd & nd & nd & nd \\
\hline
\end{tabular}

The majority of mussels collected in August 1997 and in the 1992 survey by Hartfield and Bowker (1992) were found between RM 14.3 and 10.1, approximately $11 \mathrm{~km}$ (6 miles) upriver of the construction area. A comparison of these two data sets indicates that previously described minor project-induced velocity changes had virtually no effect on total numbers of species present (Figure 2). In 1992, Hartfield and Bowker (1992) collected nine species between RM 14.3 and 11.4 and seven species between RM 14.3 and 10.1. In 1997, 9 and 10 living species were collected during this study in these same two river reaches (Figure 2). 


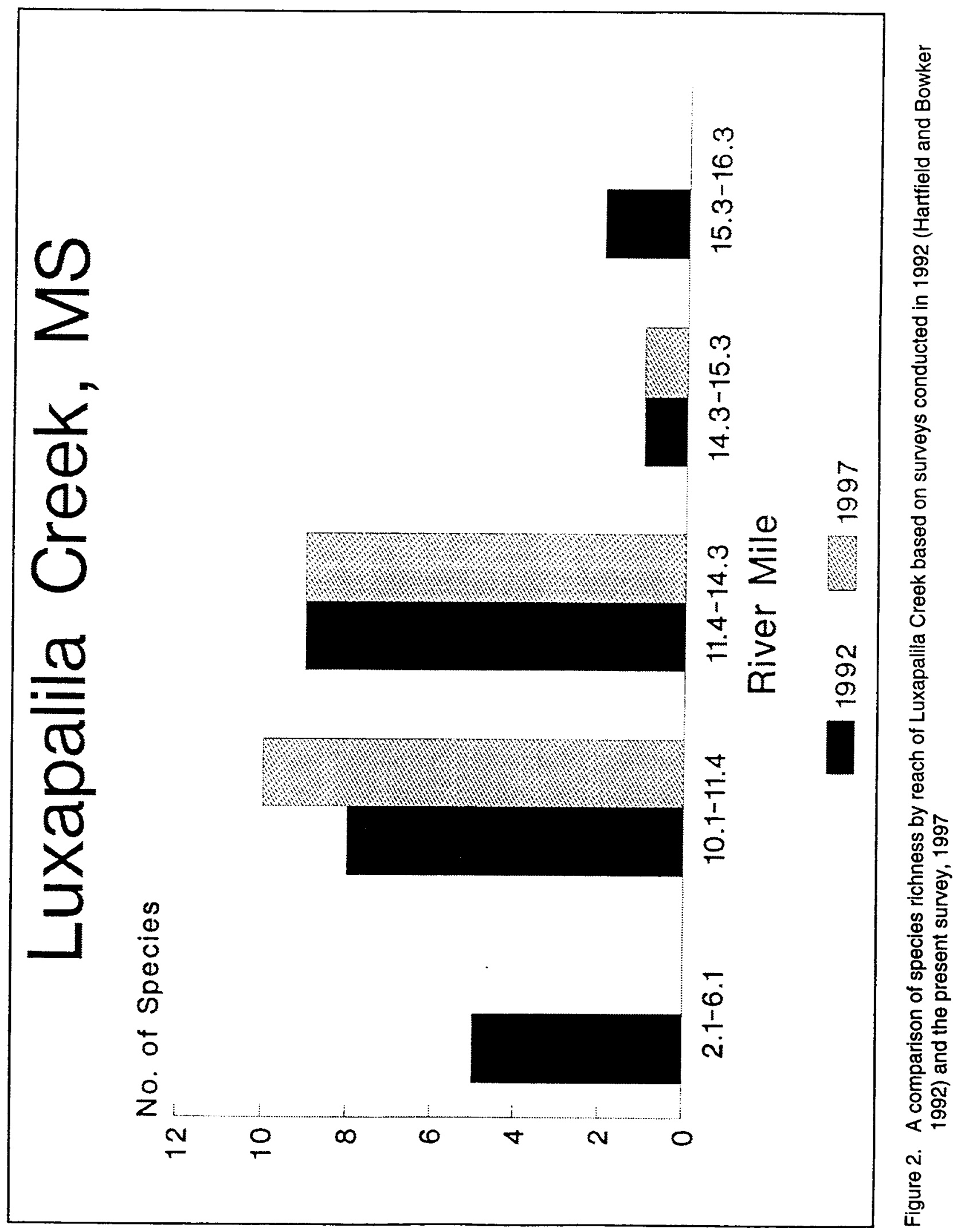


It is possible that impacts of slightly increased velocity will not be observed in this river reach for years. For example, water release schedules from Wolf Creek Dam, Tennessee, completed in 1952, eliminated mussel recruitment in the lower Cumberland River. However, adult mussels, but no juveniles, were collected in the affected reach as late as 1982 (Miller, Rhodes, and Tippit 1984).

\section{Summary and Recommendations}

\section{Characterization of the mussel resource}

In comparison with other habitats in southern rivers, the mussel fauna of Luxapalila Creek can be described as having moderate to low density (Miller and Payne 1995,1996). Although shells are commonly found on exposed bars, the number of live mussels found in riffles, runs, or pools was low. Regardless, the total number of species present, 25 , should be considered high for this small river and is a reflection of its good water quality and high habitat diversity. Typically, larger rivers support greater numbers of mussel species than smaller rivers. The molluscan resource in Luxapalila Creek should be considered valuable because of the large number of uncommon, Federally listed endemic species, such as Pleurobema perovatum (ovate clubshell), Pleurobema decisum, Medionidus acutissimus (Alabama moccasin shell), and Lampsilis perovalis (orange-nacre mucket). Although juvenile mussels were not found during this survey, it should be noted that successful recruitment each year is not required to sustain a dense and diverse community.

\section{Future studies}

Results of future studies will be important to determine if the altered water velocity is having long-term effects on the mussel fauna. Based on data collected in 1992 and 1997, it would appear that the number of species present has remained essentially unchanged (Figure 2). Although divers were used in the more recent study, since the majority of mussels were collected in shallow water by waders, results from the 1992 and 1997 study are comparable.

Most species collected during these surveys can live to be 20 or more years old. Therefore, studies will be conducted in 1998 and beyond to determine if present stocks are successfully recruiting. One or more additional sites will be added between Waterworks Road bridge and Site 10 to ensure that Luxapalila Creek has been thoroughly surveyed. Future monitoring does not necessarily have to be conducted each year. If the same sampling protocol is used (i.e., timed searches), then results can be compared with data collected from the survey conducted in 1997. 


\section{References}

Hartfield, P., and Bowker, R. (1992). "Mussel survey of Luxapalila Creek, Steens, Mississippi, to the Tombigbee River, May 11-12, 1992," Report submitted to the U.S. Army Engineer District, Mobile, from the U.S. Fish and Wildlife Service, Jackson, MS.

Isom, B. G., and Gooch, C. (1986). "Rationale and sampling design for fresh-water mussels, Unionidae, in streams, large rivers, impoundments, and lakes." Rationale for sampling and interpretation of ecological data in the assessment of freshwater ecosystems. ASTM STP 894, B. G. Isom, ed., American Society for Testing and Materials, Philadelphia, PA, 46-59.

Kovalak, W. P., Dennis, S. D., and Bates, J. M. (1986). "Sampling effort required to find rare species of freshwater mussels." Rationale for sampling and interpretation of ecological data in the assessment of freshwater ecosystems. ASTM STP 894, B. G. Isom, ed., American Society for Testing and Materials, Philadelphia, PA, 34-45.

Miller, A. C., and Payne, B. S. (1988). "The need for quantitative sampling to characterize size demography and density of freshwater mussel communities," American Malacological Bulletin 6, 49-54.

(1995). "An analysis of freshwater mussels (Unionidae) in the Big Sunflower River, Mississippi, for the Big Sunflower River maintenance project: 1993 studies," Technical Report EL-95-26, U.S. Army Engineer Waterways Experiment Station, Vicksburg, MS.

(1996). "Importance of a mussel bed near McMillan Island, Pool 10 of the Upper Mississippi River, for Lampsilis higginsi," Technical Report EL-96-9, U.S. Army Engineer Waterways Experiment Station, Vicksburg, MS.

Miller, A. C., Payne, B. S., Shafer, D. J., and Neill, L. T. (1993). "Techniques for monitoring freshwater bivalve communities and populations in large rivers." Proceedings of The Conservation and Management of Freshwater Mussels, October 12-14, 1992, St. Louis, MO. 147-158. 
Miller, A. C., Rhodes, L. and Tippit, R. (1984). "Changes in the naiad fauna of the Cumberland River below Lake Cumberland in central Kentucky," The Nautilus 98(2), 107-110.

Schultz, C. A. (1981). North Mississippi Fisheries Investigations, Mississippi Project F-47. Completion Report Tombigbee River Basin Preimpoundment Studies, Mississippi Department of Wildlife Conservation, Daphne, AL.

U.S. Fish and Wildlife Service. (1996). "Biological opinion on the Corps of Engineers' Luxapalila Creek flood control project, Lowndes County, MS," Report submitted to the U.S. Army Engineer District, Mobile, from the U.S. Fish and Wildlife Service, Jackson, MS.

Williams, J. D., Warren, M. L., Jr., Cummins, K. S., Harris, J. L., and Neves, R. J. (1993). "Conservation status of freshwater mussels of the United States and Canada," Fisheries 18(9), 6-22. 


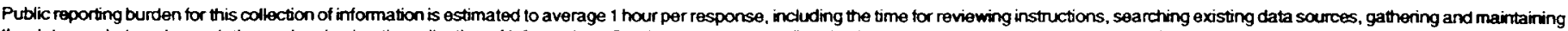

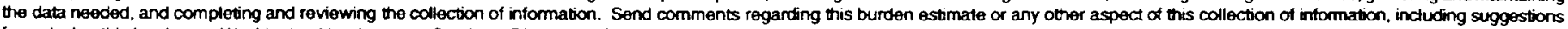

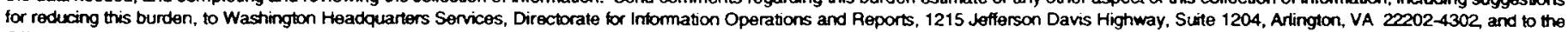
Office of Management and Budget, Paperwork Reduction Project (0704-0188). Washington. DC 20503.

\section{\begin{tabular}{|l|l|l|}
\hline 1. AGENCY USE ONLY (Leave blank) & 2. REPORT DATE & 3. REPORT TYPE AND DATES COVERED
\end{tabular} \\ \begin{tabular}{l|l} 
November 1998 & Final report
\end{tabular}}

\section{TITLE AND SUBTITLE}

An Analysis of Freshwater Mussels (Unionidae) Along Luxapalila Creek, Mississippi

6. AUTHOR(S)

Andrew C. Miller

\section{PERFORMING ORGANIZATION NAME(S) AND ADDRESS(ES)}

U.S. Army Engineer Waterways Experiment Station

3909 Halls Ferry Road

Vicksburg, MS 39180-6199

\section{PERFORMING ORGANIZATION} REPORT NUMBER

Technical Report EL-98-14

9. SPONSORINGMONITORING AGENCY NAME(S) AND ADDRESS(ES)

U.S. Army Engineer District, Mobile

P.O. Box 2288

Mobile, AL 36628-0001

\section{SUPPLEMENTARY NOTES}

Available from National Technical Information Service, 5285 Port Royal Road, Springfield, VA 22161.

\section{2a. DISTRIBUTION/AVAILABILTTY STATEMENT}

Approved for public release; distribution is unlimited.

\section{ABSTRACT (Maximum 200 words)}

In 1997 divers and waders were used to search for freshwater mussels in Luxapalila Creek between Steens, MS, and Waterworks Road bridge (River Mile 6.2). The purpose was to obtain information that could be used to assess the effectiveness of reasonable and prudent measures and their terms and conditions to reduce impacts to mussels caused by downstream channelization. In addition, results would be used to determine the likelihood of future losses (or incidental take) of federally listed mussel species in the project area. Luxapalila Creek is within the range of the following endemic mussels: Pleurobema perovatum (ovate clubshell mussel) and Pleurobema decisum (southern clubshell mussel), listed as endangered; and Medionidus acutissimus (Alabama moccasinshell mussel) and Lampsilis perovalis (orange-nacre mucket mussel), listed as threatened. Fifteen species of bivalves, including Corbicula fluminea (Asian clam), were collected. Two federally listed endemic species were found: live specimens of $L$ perovalis and shells of $P$. decisum. The most abundant living species were Quadrula asperata (Alabama orb) and Lampsilis straminea claiborensis (southern fatmucket), which comprised 44.3 and 19.3 percent of the fauna. The third most abundant species, Lampsilis ornata (southern pocketbook), comprised slightly more than 10 percent of the collection, and the remaining 12 species (including $C$. fluminea) each comprised less than 6 percent of the fauna. The species list for this creek is now 25 . When these results were compared with findings from a study conducted by the U.S. Fish and Wildlife Service in 1992, it was determined that there have been few recent changes in the mussel community.

\section{SUBJECT TERMS}

Luxapalila Creek, Mississippi

Mussels

Unionidae
15. NUMBER OF PAGES

23

\section{PRICE CODE}

\begin{tabular}{|l|c|c|c|}
\hline $\begin{array}{l}\text { 17. SECURITY CLASSIFICATION } \\
\text { OF REPORT }\end{array}$ & $\begin{array}{c}\text { 18. SECURITY CLASSIFICATION } \\
\text { OF THIS PAGE } \\
\text { UNCLASSIFIED }\end{array}$ & $\begin{array}{l}\text { 19. SECURTY CLASSIFICATION } \\
\text { OF ABSTRACT }\end{array}$ & 20. LIMITATION OF ABSTRACT \\
\hline
\end{tabular}

NSN 7540-01-280-5500 